\title{
A STUDY ON MENTAL HEALTH AND LIFE SATISFACTION AMONG MANAGEMENT STUDENTS
}

KEY WORDS: Gender, life satisfaction, mental health, religion

\section{Neha Perween*}

Research fellow, University Department of Psychology, Ranchi University, Ranchi. *Corresponding Author

The present study aims to investigate the impact of gender and religion on mental health and life Satisfaction among management students. The sample was consisted of 100 management students selected by stratified random sampling from different institutions located in Ranchi town. The stratification was based on two groups of gender (Boys \& girls) and religion (Hindu and Muslim). In total, there were four sample sub - groups based on $2 \times 2$ factorial design and for each sample sub- group, 25 cases were selected randomly. General Health Questionnaire (GHQ)-12 by Shamsunder et al. (1986) and Goutam et al. (1987) was applied to measure the level of mental health and Life Satisfaction Scale by Alam (2001) was used to find out the level of life satisfaction among the student sample. ANOVA and Correlation were used to analyze the data by SPSS. The results revealed that there was no significant effect of gender and religion on mental health and life satisfaction of the students. And co-relation between mental health and life satisfaction was found significant.

\section{INTRODUCTION}

As we all know that good mental health and physical health are essential for all human being. Person having good mental health can do all the activities full of enthusiasm by maintaining balance between various activities of life and efforts to achieve psychological resilience

Menninger (1945) writes "Mental Health as the adjustment of human being to the world and to each other with a maximum of effectiveness and happiness...... It is the ability to minimum an even temper, an alert intelligence, socially considerate behaviour and a happy disposition"

A person feelings and attitudes convergence from negative to positive is a good assessment towards life satisfaction can be considered that the person is satisfied in his life

Life satisfaction is an overall assessment of feelings and attitudes about one's life at a particular point in time ranging from negative to positive. It is one of three major indicators of well-being: life satisfaction, positive effect and negative affect (Diener, 1984).

Droogenbroeck et al (2018) studied on gender differences in mental health problems among adolescent and the role of social support and found that distress, anxiety and depression with girls reporting significantly higher scores than boys.

Sirohi (2002) conducted a study on the effect of religion on mental health. The sample consisted of $250 \mathrm{XI}$ standard boys covering three religions. . He reported that Christian had significantly poor mental health when compared with Hindu and Muslim boys.

Gropel (2001) found that women scored higher than men in emotional wellbeing as well as in life satisfaction.

Fergusson, McLeod, Horwood and Swain (2015) studies that mental health was strongly associated with life satisfaction

Raj, Kumar and Verma (2017) examined the relationship between life satisfaction and mental health on research scholars from (TISS) \& (IIPS). Found the role of life satisfaction in determining mental health of the research scholars.

\section{METHODOLOGY}

\section{Objectives}

i. To study the significant impact of gender and religion on mental health and life satisfaction of the students.

ii. To study the inter-relationship between mental health and life satisfaction.

\section{Hypotheses}

i. There may be significant impact of gender and religion on mental health of the students.

ii. There may be significant impact of gender and religion on life satisfaction of the students.

iii. There may be significant relationship between mental health and life satisfaction.

\section{Research Design}

\section{a) Sample}

The sample of present study was consisted of 100 management students selected by stratified random sampling from different management institutions in Ranchi town. In total there were 4 sample sub-groups based on $2 \times 2$ factorial design and for each sample sub- group, 25 cases were selected randomly.

The criteria of the stratification were:-

- Gender-2 (Boys \& girls)

- Religion-2 (Hindu and Muslim)

\section{b) Research Design}

Table-1:

\begin{tabular}{|l|l|l|l|l|}
\hline Gender & \multicolumn{3}{|l|}{ Male } & Female \\
\hline \multirow{2}{*}{ Religion } & Hindu & Muslim & Hindu & Muslim \\
\cline { 2 - 5 } & 25 & 25 & 25 & 25 \\
\hline Total & 50 & 50 & \\
\hline Grand Total & 100 & & \\
\hline
\end{tabular}

\section{C)Tools:}

\section{i. Personal Data Questionnaire:}

This questionnaire was designed by the researcher to collect information about the respondents' personal history viz. name, age, gender, religion, education, Institution, place of residence, family income and occupation etc.

\section{ii. General Health Questionnaire (G.H.Q.) -12:}

General Health Questionnaire (G.H.Q.)-12 was developed by David Goldberg and Paul Williams, (1979). Hindi version was developed by Shamsunder et.al, (1986) and Goutam et.al, (1987). It consists 12 questions .It has four response alternatives. Reliability of the test was 0.83 determined by test - retest method and the validity was 0.73 .

\section{iii. Life Satisfaction Scale}

This test was developed by Q. J. Alam and Ramji Srivastava (2001) which consists of 60 items related to 6 areas :Health,Personal,Economics,Marital,Social,Job

Every item has to be responded either in 'yes' or 'no'. There is no other alternative. Every 'yes' response is assigned 1 score. The test retest reliability was 0.84 . The validity of the scale was 
obtained by correlating it with Saxena's Adjustment Inventory and Srivastava's Adjustment Inventory. The quotient obtained was .74 and .82 respectively.

Results \& Analysis

Table-2: Analysis Of Variance (ANOVA) Showing The Impact Of Gender And Religion On Mental Health:

\begin{tabular}{|l|l|l|l|l|l|l|}
\hline Mental Health & & & & \\
\hline $\begin{array}{l}\text { Sources of } \\
\text { Variations }\end{array}$ & $\begin{array}{l}\text { Sum of } \\
\text { quare }\end{array}$ & df & Mean Square & F Value & $\begin{array}{l}\text { Level of } \\
\text { Significance }\end{array}$ \\
\hline $\begin{array}{l}\text { Main Effects } \\
\text { A. Gender }\end{array}$ & 1 & 1 & 1 & 2.15 & NS \\
\hline B. Religion & 0.36 & 1 & 0.36 & 0.78 & NS \\
\hline $\begin{array}{l}\text { Interaction } \\
\text { Effects } \\
\text { A X B }\end{array}$ & 0.04 & 1 & 0.04 & 0.09 & NS \\
\hline $\begin{array}{l}\text { Within } \\
\text { (Error) }\end{array}$ & 44.6 & 96 & 0.46 & & \\
\hline
\end{tabular}

NS:Not Significant

\section{Main Effects}

- The $F$ value of gender is 2.15 , which is found statistically not significant. It shows that boys \& girls students did not differ significantly on mental health.

- The $F$ value of religion is 0.78 , which is also found statistically not significant. It indicates that Hindu and Muslim students did not differ significantly on mental health.

\section{Interaction Effects}

- The F value of $A \times B$ (Gender and Religion) factors is 0.09 , which is found statistically not significant. It indicates that gender and religion jointly did not effect on mental health of the sample.

- It shows that boys \& girls of Hindu and Muslim sample have same level of mental health.

\section{Above results has not proved the Hypothesis (i)}

There may be significant impact of gender and religion on mental health of the students.

Table-3: Analysis Of Variance (ANOVA) Showing The Impact Of Gender And Religion On Life Satisfaction:

\begin{tabular}{|l|l|l|l|l|l|}
\hline \multicolumn{5}{|l|}{ Life Satisfaction } \\
\hline $\begin{array}{l}\text { Sources of } \\
\text { Variations }\end{array}$ & $\begin{array}{l}\text { Sum of } \\
\text { Square }\end{array}$ & Df & $\begin{array}{l}\text { Mean } \\
\text { Square }\end{array}$ & F Value & $\begin{array}{l}\text { Level of } \\
\text { Significance }\end{array}$ \\
\hline $\begin{array}{l}\text { Main } \\
\text { Effects } \\
\text { A. Gender }\end{array}$ & 174.11 & 1 & 174.11 & 2.82 & NS \\
\hline B. Religion & 124.92 & 1 & 124.92 & 2.02 & NS \\
\hline $\begin{array}{l}\text { Interaction } \\
\text { Effects } \\
\text { A X B }\end{array}$ & 2.45 & 1 & 2.45 & 0.04 & NS \\
\hline $\begin{array}{l}\text { Within } \\
\text { Error) }\end{array}$ & 5929.73 & 96 & 61.77 & & \\
\hline
\end{tabular}

NS:Not Significant

\section{Main Effects}

- The F value of gender is 2.82 , which is found statistically not significant. It shows that boys \& girls students did not differ significantly on life satisfaction.

- The F value of religion is 2.02 , which is also found statistically not significant. It indicates that Hindu and Muslim students did not differ significantly on life satisfaction.

\section{Interaction Effects}

- The F value of $A \times B$ (Gender and Religion) factors is 0.04 , which is found statistically not significant. It indicates that gender and religion jointly did not effect on life satisfaction of the sample.

- It indicates that boys \& girls of Hindu and Muslim sample have same level of life satisfaction.

Above results has not proved the Hypothesis(ii)

"There may be significant impact of gender and religion on life satisfaction of the students'.

Table - 4: Inter-correlation Between Mental Health And Life Satisfaction On Total Sample. (total Sample =100)

\begin{tabular}{|l|l|l|}
\hline & Life Satisfaction & P-Value \\
\hline Mental Health & $0.686 * *$ & 0.01 level \\
\hline
\end{tabular}

\section{** Significant at 0.01 level}

- Above table 4 reveals that there is a significant positive relationship between mental health and life satisfaction. 0.686 has been found which is significant at 0.01 level.

- Above results has proved the Hypothesis (iii)'There may be significant positive correlation between mental health and life satisfaction'.

\section{CONCLUSION}

It was concluded from the above analysis that there has been no significant impact of gender and religion on mental health and life satisfaction of the students. It was also revealed that mental health and life satisfaction is positively co related to each other.

\section{REFERENCES}

1. Diener, E. (1984). Subjective well-being. Psychological Bulletin, 95(3): 542-575.

2. Fergusson, D., McLeod, G., Horwood, L., Swain, N., Chapple, S., \&Poulton, R. (2015). Life satisfaction and mental health problems (18 to 35 years). Psychological Medicine,45(11),2427-2436.doi:10.1017/S003329171500042.

3. Fink E, Patalay P, Sharpe H, Holley S, Deighton J, Wolpert M.(2015) .Mental Health Difficulties in Early Adolescence: A Comparison of Two Cross-Sectional Studies in England From 2009 to 2014. J Adolesc 56(5):502-507.doi:10.1016/j. jadohealth.2015.01.023

4. Menninger,K.A. (1945). Human Mind,NewYork:Sage.

5. Menninger, K.A. (1945). The Quarterly Review of Biology, 20(4):408-409.

6. Sirohi, M. S., 2002, Differential effects of religions on personality development, mental health and religiosity of adolescent students. J. Edu. Res. Extn., 39 (2): 1-19.

7. Van Droogenbroeck, F., Spruyt, B. \& Keppens, G. (2018)Gender differences in mental health problems among adolescents and the role of social support: results from the Belgian health interview surveys 2008 and 2013. BMC Psychiatry 18, (6).https://doi.org/10.1186/s12888-018-1591-4 